\title{
CAPAIAN STANDAR NASIONAL PENDIDIKAN SEBAGAI PREDIKTOR MUTU SEKOLAH
}

\section{ACHIEVEMENT OF NATIONAL STANDARDS OF EDUCATION AS A PREDICTOR OF SCHOOL QUALITY}

\author{
Sabar Budi Raharjo \\ Pusat Penelitian Kebijakan Pendidikan dan Kebudayaan, Balitbang Kemdikbud \\ Gedung E lantai 19, Jl. Jenderal Sudirman- Senayan- Jakarta Pusat \\ E-mail: raharjo2sbr@gmail.com
}

\author{
Lia Yuliana \\ Fakultas Ilmu Pendidikan Universitas Negeri Yogyakarta \\ Jl. Colombo No.1 Yogyakarta \\ E-mail: lia_yuliana@uny.ac.id \\ Yusuf Hadi Yudha \\ Fakultas Psikologi Universitas Pancasila \\ E-mail: yudha@univpancasila.ac.id
}

Naskah diterima tanggal: 05-02-2018, disetujui tanggal: 13-11-2018

\begin{abstract}
This research is to obtain information about the achievement of National Education Standards as a predictor or which of them has a significant effect on school quality. The research used a quantitative descriptive approach and secondary data from BAN-SM Year 2015. From the data, 506 A acrredited schools were selected as sample. Those schools then were ranked from the lowest to the highest score to be made quartile score. The results showed that, based on A accredited schools grouped on the average quantitative achievement of the National Exam, it did not show significant difference among quartiles 3, 4 and 5. In addition, the effect of the fulfillment of the eight of National Education Standards of Education on the achievement of school quality (National Exam value) simultaneously statistically significant. Standards which have a significant influence on school quality are the standard of Content, Graduate Competencies, Educators and Educational Personnel, Facilities \& Infrastructure, and Management. The results indicated that there were only five standards that have positive and significant effect on the achievement of school quality, while the other three standards, namely, Process, Financing and Assessment had no significant effect.
\end{abstract}

Keywords: national standard of education, school quality, quality predictor

Abstrak: Penelitian ini bertujuan untuk memperoleh informasi tentang capaian Standar Nasional Pendidikan sebagai prediktor atau yang berpengaruh secara signifikan terhadap mutu sekolah. Metode penelitian yang digunakan adalah pendekatan deskriptif kuantitatif. Penelitian ini menggunakan data sekunder dari BAN-SM Tahun 2015. Dari data tersebut, dipilih 506 sekolah sampel yaitu provinsi yang mendapat akreditasi A dan diurutkan mulai dari skor terendah sampai yang tertinggi untuk dibuat kuantil skor. Hasil penelitian menunjukkan bahwa, pertama, berdasarkan sekolah hasil akreditasi A dan dikelompokkan pada kuantil rata-rata capaian UN tidak menunjukkan perbedaan secara signifikan antarkuantil 3, 4 dan 5. Kedua, pengaruh pemenuhan kedelapan Standar Nasional Pendidikan terhadap pencapaian mutu sekolah (Nilai UN) secara bersama-sama (simultan) signifikan 
secara statistik. Dari kedelapan SNP, yang memiliki pengaruh signfikan terhadap mutu sekolah adalah Standar Isi, Kompetensi Lulusan, Pendidik dan Tenaga Kependidikan, Sarana \& Prasarana, serta Pengelolaan. Dengan demikian, hanya ada lima standar yang berpengaruh secara positif dan signifikan terhadap pencapaian mutu sekolah. Sementara tiga standar lainnya yaitu standar proses, standar pembiayaan, dan standar penilaian berpengaruh positif tetapi tidak signifikan.

Kata kunci: Standar Nasional Pendidikan, mutu sekolah, prediktor mutu

\section{PENDAHULUAN}

Akreditasi sekolah dapat dijadikan sebagai ukuran ketercapaian mutu suatu sekolah karena akreditasi adalah salah satu instrumen dari pemerintah untuk mengetahui kondisi mutu pendidikan baik pada tingkat kabupaten/kota, tingkat provinsi, maupun tingkat nasional. Lembaga yang mendapat mandat secara independen untuk melakukan akreditasi terhadap delapan Standar Nasional Pendidikan (SNP) pada satuan pendidikan yaitu Badan Akreditasi Nasional Sekolah/Madrasah (BAN S/M). Pada era sekarang ini, terhadap semua lembaga layanan masyarakat diperlukan standardisasi agar masyarakat mengetahui secara transparan mutu layanan yang dilakukan oleh suatu lembaga yang dibiayai dari anggaran negara dapat tercapai. Masyarakat harus terlindungi hakhaknya untuk mendapatkan layanan yang bermutu. Hal tersebut juga berlaku pada bidang pendidikan bahwa masyarakat mempunyai hak untuk mendapat layanan pendidikan yang bermutu. Pasal 5 Undang-undang Nomor 20 Tahun 2003 tentang Sistem Pendidikan Nasional mengamanatkan bahwa setiap warga negara mempunyai hak yang sama untuk memperoleh pendidikan yang bermutu (Republik Indonesia, 2003).

Negara mempunyai kewajiban dalam memberikan layanan pendidikan yang bermutu kepada setiap warga negara melalui penyelenggaraan pendidikan pada satuan pendidikan. Pelaksanaan pendidikan melibatkan faktor internal maupun eksternal satuan pendidikan. Faktor internal meliputi kepala sekolah, guru, tenaga administrasi serta ketersediaan dan ketercukupan sarana prasarana pendidikan. Faktor eksternal mencakup dinas pedidikan dan masyarakat termasuk orang tua peserta didik. Pada faktor internal kemampuan kepala sekolah, tenaga pendidik, dan tenaga kependidikan dalam memberdayakan sekolah masih perlu ditingkatkan. Sarana dan prasarana pada beberapa satuan pendidikan jenjang SMA masih ada yang belum mencapai standar dalam layanan pendidikan.

Kondisi tersebut tercermin dari hasil akreditasi BAN S/M Tahun 2015. Akreditasi dari 1450 sekolah menengah atas (SMA) menunjukkan capaian Standar Isi (81), Standar Proses (79), Standar tenaga kependidikan (75), Standar Pengelolaan (80), Standar Sarana prasarana (72), Standar Biaya (83), Standar Penilaian (81), Standar Kompetensi Kelulusan (76). Target capaian pemerintah minimal 80. Dengan demikian, terdapat beberapa standar yang belum tercapai. Dalam memberikan layanan pendidikan yang bermutu perlu melakukan pemenuhan setiap Standar Nasional Pendidikan melalui program-program pemerintah atau keterlibatan masyarakat. Indikator lain yang dapat menunjukkan peta mutu pendidikan yang dicapai yaitu dari Pusat Data Statistik Pendidikan Tahun 2014/2015 pada jenjang SMA seperti pada pada Tabel 1.

Berdasarkan indikator pendidikan pada jenjang SMA angka lulusan sudah mencapai $98,98 \%$ dari target pemerintah sebesar $99.5 \%$. Siswa mengulang sebanyak $0,63 \%$ atau 27,048 siswa. Siswa yang putus sekolah menunjukkan angka 1,59\% atau 68,219 siswa. Kondisi guru yang layak mengajar untuk jenjang SMA 
Tabel 1 Persentase Angka Nilai Indikator Jenjang Pendidikan Menengah (SMA)

\begin{tabular}{lrrr}
\hline & Siswa & Mengulang & Angka Mengulang \\
Angka Mengulang & $2013 / 2014$ & 27,048 & 0.63 \\
& $4,292,288$ & & Angka Putus \\
& Siswa & Putus Sekolah & 1.59 \\
\hline Angka Putus Sekolah & $2013 / 2014$ & 68,219 & Angka Lulusan \\
& $4,292,288$ & & 98.98 \\
\hline Angka Lulusan & Siswa Tk. XII & Lulusan & \% Siswa baru \\
& $13 / 14$ & $1,429,795$ & 92.89 \\
\hline $\begin{array}{l}\text { Persentase Siswa } \\
\text { Baru terhadap }\end{array}$ & Pendaftar & Siswa Baru & terhadap pendaftar \\
Pendaftar & $1,548,388$ & $1,438,298$ & K Guru Layak \\
\hline $\begin{array}{l}\text { Persentase Guru } \\
\text { Layak Mengajar }\end{array}$ & KS dan Guru & KS \& Guru & Layak \\
terhadap KS dan & & 342,277 & 94.37 \\
Guru seluruhnya & 362,693 & & \\
\hline
\end{tabular}

Kementerian Pendidikan dan Kebudayaan (2015)

mencapai 94,37\%. Hal ini diduga bahwa masih ada $5,63 \%$ guru SMA yang tidak layak mengajar dan juga menunjukkan bahwa mutu pendidikan pada jenjang SMA masih perlu perbaikan pada penyelenggaraan proses belajar-mengajar. Perbaikan dimaksud, di antaranya pada peningkatan kompetensi guru dan kompetensi kepala sekolah.

Indikator lain yang dapat memberikan gambaran capaian mutu pendidikan yaitu Ujian Nasional (UN). Pemerintah melalui UN dapat melihat peta mutu yang dicapai mulai pada tingkat satuan pendidikan kabupaten/kota, propinsi, hingga tingkat nasional. UN berfungsi sebagai kontrol mutu dari luar satuan pendidikan. UN juga dapat memberikan informasi ketercapaian ketuntasan belajar pada satuan pendidikan. Manfaat UN bagi satuan pendidikan maupun pemerintah sangat penting dalam melakukan kebijakan perbaikan mutu melalui program-program pemerintah pada bidang pendidikan. Hasil UN pada 2013 rata-rata 6,36, 2014 rata-rata 6,14 dan 2015 rata-rata 6,19. Kecendereungan yang secara umum menurun sejak tahun 2013-2015 mengindikasikan bahwa hasil UN masih belum memuaskan. Oleh karena itu, semua komponen yang terlibat dalam peningkatan mutu pendidikan secara bersamasama harus melakukan perbaikan kinerja sehingga dapat mendukung perbaikan mutu pendidikan.

Data lain dari hasil pengukuran Program for International Student Assessment (PISA) Tahun 2015 (OECD, 2016) menjelaskan bahwa dari 70 negara, siswa Indonesia menempati urutan ke64 dalam hal kemampuan membaca. Gambaran skor tersebut mencermikan budaya literasi bangsa berada pada titik kiritis meskipun kini informasi menyerbu kita dari berbagai penjuru (Saraswati, 2017). Lebih lanjut Saraswati mengemukakan bahwa hasil studi internasional Trends in Internastional Matehematic \& Science Study (TIMSS MATH) tahun 2015 dari 50 negara, Indonesia berada pada peringkat ke-45. Hasil tersebut menunjukkan bahwa kemampuan siswa Indonesia di bidang Matematika dan ilmu pengetahuan masih tergolong rendah. 
Berdasarkan data di atas, Standar Nasional Pendidikan secara umum belum dicapai oleh setiap satuan pendidikan di Indonesia. Faktor yang menentukan adalah tenaga pendidik atau guru sebagai ujung tombak dalam transfer pengetahuan dan keterampilan kepada siswa. Hal ini terjadi pada proses belajar mengajar dan ini juga terkait pada Standar Proses yang diperankan oleh guru. Ketercapaian Standar Proses sangat erat dengan ketercapaian Standar Tenaga Pendidikan dan Kependidikan.

Ketika guru menjalankan tugas dalam proses belajar mengajar di kelas, mereka harus memiliki kompetensi mengajar. Peraturan Pemerintah Nomor 19 Tahun 2005 pasal 28 ayat 3 menyebutkan bahwa pendidik harus memiliki kompetensi pedagogi kepribadian, profesional, dan sosial. Pendidik harus menjalankan tugas dengan profesional dengan kompetensi tersebut. Namun demikian, guru masih belum menunjukkan kemampuan yang optimal. Kompetensi guru terkait dengan pelaksanaan proses belajar mengajar dan kemampuan melakukan penilaian hasil belajar. Penilaian merupakan serangkaian kegiatan untuk memperoleh, menganalisis, dan menafsirkan data tentang proses dan hasil belajar peserta didik yang dilakukan secara sistematis dan berkesinambungan, sehingga menjadi informasi yang bermakna dalam pengambilan keputusan (Widyastono, 2013).

Dengan hasil penilaian tersebut guru dapat mengkaji dan menganalisis perbaikan proses belajar dengan mengubah metode mengajar dan strategi belajar. Hasil belajar merupakan kemampuan yang dimiliki seseorang setelah ia menerima pengalaman belajar. Kemampuan tersebut bersifat relatif permanen dan bermanfaat bagi dirinya (Prayekti, 2013). Hasil belajar dapat diwujudkan melalui penilaian oleh internal maupun eksternal. Penilaian internal dilakukan oleh guru pada saat pelaksanaan proses belajar. Penilaian ekternal dilakukan oleh pemerintah melalui UN. UN yang diselenggarakan oleh pemerintah merupakan salah satu intrumen untuk melihat mutu pendidikan. UN dapat menentukan tingkat kemampuan peserta didik di seluruh Indonesia berdasarkan standar nasional yang telah ditetapkan. Nilai perolehan siswa dapat dibandingkan dengan siswa lain antarsekolah, antarkabupaten, dan antarprovinsi di seluruh Indonesia karena menggunakan kisi-kisi UN yang berstandar nasional (Safari, 2015).

Standar lain yang mendukung tercapainya proses belajar yaitu Standar Isi, Standar Pengelolaan, Standar Pembiayaan, Standar Sarana dan Prasarana. Pemenuhan delapan Standar Nasional Pendidikan tersebut akan dapat memberikan kontribusi pada ketercapaian mutu pendidikan secara keseluruhan.

Penyelenggaraan pendidikan yang bermutu tidak terlepas dari ukuran standar yang akan dicapai. Pemerintah mengeluarkan kebijakan melalui Peraturan Pemerintah Nomor 19 Tahun 2005 tentang Standar Nasional Pendidikan. Kebijakan tersebut bertujuan mewujudkan visi dan menjalankan misi pendidikan nasional. Acuan dasar atau patok-duga (benchmark) diperlukan oleh setiap penyelenggara dan satuan pendidikan yang meliputi kriteria minimal dari berbagai aspek yang terkait penyelenggaraan pendidikan. Standar Nasional Pendidikan (SNP) adalah salah satu indikator ketercapaian visi dan misi pendidikan nasional karena dapat memberikan gambaran mutu pendidikan pada tingkat satuan pendidikan kabupaten/kota, provinsi, dan nasional. Oleh karena itu, semua pihak harus berupaya untuk memenuhi SNP khususnya pada tingkat satuan pendidikan.

Penyelenggaraan pendidikan nasional pada tahun 2005, Indonesia memiliki perangkat pelaksanaan Undang-Undang Nomor 20 Tahun 2003 tentang Sistem Pendidikan Nasional berupa Peraturan Pemerintah Nomor 19 Tahun 2005 tentang Standar Nasional Pendidikan. Seiring dengan perubahan kurikulum menuju penyelenggaraan pendidikan yang semakin baik yang sesuai dengan kebutuhan dan perkembangan 
zaman, maka pada tahun 2013 Standar Nasional Pendidikan berubah menjadi Peraturan Pemerintah Nomor 32 Tahun 2013. Dalam rumusannya Standar Nasional Pendidikan didefinisikan sebagai kriteria minimal tentang sistem pendidikan di seluruh wilayah hukum Negara Kesatuan Republik Indonesia.

Adanya perubahan Peraturan Pemerintah Nomor 19 tahun 2005 menjadi Peraturan Pemerintah Nomor 32 tahun 2013 merupakan upaya pemerintah dalam rangka peningkatan mutu dan daya saing sumber daya manusia Indonesia. Rencana Pembangunan Jangka Menengah Nasional 2010-2014 menyebutkan bahwa salah satu substansi inti program aksi bidang pendidikan adalah penataan ulang kurikulum sekolah yang dapat mendorong dan mampu menjawab kebutuhan sumber daya manusia untuk mendukung pertumbuhan nasional dan daerah (Kementerian Perencanaan Pembangunan Nasional/Bappenas, 2009). Dengan demikian pemantapan Standar Nasional Pendidikan dan pengaturan kurikulum secara utuh sangat penting dan mendesak dilakukan untuk mencapai tujuan tersebut.

Peraturan Pemerintah Nomor 19 Tahun 2005 tentang Standar Nasional Pendidikan perlu diselaraskan dengan dinamika perkembangan masyarakat, baik lokal, nasional, maupun global guna mewujudkan fungsi dan tujuan pendidikan nasional. Standar Kompetensi Lulusan, Standar Isi, Standar Proses, dan Standar Penilaian mendesak disempurnakan untuk membangun kurikulum pendidikan. Selain itu, ide, prinsip, dan norma yang terkait dengan kurikulum dirasakan penting untuk dikembangkan secara komprehensif dan diatur secara utuh pada satu bagian tersendiri.

Pemerintah selalu berupaya untuk meningkatkan mutu pendidikan melalui berbagai kebijakan, antara lain sertifikasi guru dan dosen, bantuan operasional sekolah, pemberian block grant dan menetapkan standar nasional yang dituangkan dalam Peraturan Pemerintah Nomor
19 Tahun 2005 Tentang Standar Nasional Pendidikan. Standar nasional pendidikan meliputi standar isi, proses, ketenagaan, sarana dan prasarana, pengelolaan, evaluasi, pembiayaan dan kompetensi lulusan.

Dengan adanya standar nasional tersebut, maka arah peningkatan mutu pendidikan Indonesia menjadi lebih jelas. Apabila setiap satuan pendidikan telah dapat mencapai atau melebihi standar nasional pendidikan tersebut, maka kualitas satuan pendidikan dapat dinyatakan tinggi. Berbagai kebijakan yang mendorong peningkatan mutu pendidikan telah ditetapkan dan diimplementasikan dengan harapan mutu pendidikan dapat berangsurangsur meningkat. Berkenaan dengan hal tersebut, maka akan dievaluasi bagaimana perkembangan kualitas pendidikan di Indonesia sebagai akibat adanya kebijakan-kebijakan tersebut. Evaluasi mutu pendidikan akan didasarkan pada SNP yang telah diimplementasikan. Dewasa ini mutu bukan hanya menjadi masalah dan kepedulian dalam bidang bisnis, melainkan juga dalam bidang-bidang lainnya. Seperti pemerintahan, pelayanan sosial, pendidikan bahkan bidang keamanan dan ketertiban (Sukmadinata, 2003)

Mutu pendidikan merupakan keniscayaan yang diharapkan dari penyelenggaraan pendidikan di tanah air. Goetsch \& Davis (2006) memberikan definisi tentang mutu adalah pernyataan yang dinamis yang terkait dengan produk, pelayanan, orang, proses dan lingkungan yang dapat memenuhi atau melebihi yang diharapkan.

Selanjutnya Lochmiller (2014) mendefinisikan kualitas memiliki dua dimensi yaitu (a) kualitas dan kepuasan pelanggan merupakan hal yang sama, karena bila pelanggan mendapatkan kualitas barang atau jasa, maka akan memperoleh kepuasan; (b) Kualitas merupakan konsep yang luas yang bukan hanya kualitas produk, tetapi juga kualitas orang, proses kerja, dan setiap aspek dari organisasi. Walaupun 
demikian, agar mutu tetap terjaga dan proses peningkatan mutu tetap terkontrol, harus ada standar yang diatur dan disepakati secara nasional untuk dijadikan indikator evaluasi keberhasilan peningkatan mutu (benchmarking) (Cahyana, 2010)

Dalam mencapai mutu pendidikan dalam Peraturan Nomor 19 tahun 2005, SNP memuat kriteria minimal tentang komponen pendidikan. Kriteria tersebut memungkinkan setiap jenjang dan jalur pendidikan mengembangkan pendidikan secara optimal sesuai dengan karakteristik dan kekhasan programnya. Demikian juga SNP untuk jalur pendidikan nonformal yang hanya mengatur hal-hal pokok untuk memberikan keleluasaan kepada masing-masing satuan pendidikan pada jalur pendidikan nonformal yang memiliki karakteristik tidak terstruktur dalam mengembangkan programnya sesuai dengan kebutuhan masyarakat (Robinson, 2009). Penyelenggaraan pendidikan jalur informal yang sepenuhnya menjadi kewenangan keluarga dan masyarakat didorong dan diberikan keleluasaan dalam mengembangkan program pendidikannya sesuai dengan kebutuhan keluarga dan masyarakat.

Dengan ketercapaian mutu pendidikan yang belum maksimal tersebut perlu dilakukan analisis keterkaitan antara capaian standar nasional pendidikan dengan capaian mutu sekolah. Permasalahan penelitian ini adalah bagaimana capaian Standar Nasional Pendidikan sebagai prediktor atau yang berpengaruh secara signifikan terhadap mutu sekolah? Oleh karena itu maka penelitian ini bertujuan untuk memperoleh informasi tentang capaian Standar Nasional Pendidikan sebagai prediktor atau yang berpengaruh secara signifikan terhadap mutu sekolah.

\section{METODE}

Metode penelitian ini menggunakan pendekatan deskriptif kuantitatif. Penelitian ini menggunakan data sekunder dari BAN SM Tahun 2015. Data hasil akreditasi 2015 setiap provinsi yang dipilih sebagai sampel hanya sekolah yang mendapat akreditasi A. Data tersebut diurutkan mulai yang terendah sampai yang tertinggi untuk dibuat kuantil skor.

Jumlah sampel sekolah yang berstatus akreditasi A menurut BAN SM Tahun 2015 sebanyak 506. Pembagian kuantil yang dilakukan menggunakan tahapan-tahapan. Pertama, mencari batas kuantil dengan cara menghitung nilai persentil ke-20 (P20), P40, P60 dan P80. Hasil perhitungan persentil $(P 20)=87.0357$, $(P 40)=89.3593,(P 60)=91.2872,(P 80)=$ 93.6547. Selanjutnya, membagi kuantil berdasarkan nilai persentil dengan pembagian. Kuantil 1 nilai akhir akreditasi kurang dari atau sama dengan P20, kuantil 2 nilai akhir akreditasi di antara P20 - P40, kuantil 3 nilai akhir akreditasi di antara P40 - P60, kuantil 4 nilai akhir akreditasi di antara P60 - P80, dan kuantil 5 nilai akhir akreditasi lebih dari P80. Dengan demikian, nilai akhir akreditasi sekolah pada kuantil 5 adalah yang paling tinggi, diikuti kuantil 4, dan seterusnya. Dari data kuantil berdasarkan hasil akreditasi A persekolah dicari hasil ratarata perolehan hasil UN Tahun 2015. Analisis tersebut digunakan sebagai dasar untuk menjawab pertanyaan penelitian sehingga dapat menggambarkan kaitan antara hasil akreditasi yang diperoleh dengan mutu pendidikan yang diperoleh dari hasil UN. Uji perbandingan nilai UN menurut kelompok kuantil nilai akhir akreditasi (Peringkat A) dilakukan dengan teknik analisis Single-Factor ANOVA. Tujuannya adalah menguji perbedaan mean antara lebih dari dua kelompok. Hipotesis: $\mathrm{Ho}: \mu \mathrm{K} 1=\mu \mathrm{K} 2=\mu \mathrm{K} 3=\mu \mathrm{K} 4=\mu \mathrm{K} 5=$ 0 .

\section{HASIL DAN PEMBAHASAN}

Secara umum pemenuhan SNP jenjang SMA dapat dikategorikan baik dan amat baik. Namun, hal ini tidak selalu diikuti dengan tingginya mutu sekolah tersebut. Mutu sekolah menurut peringkat akreditasi hanya berbeda pada sekolah dengan peringkat akreditasi A dengan B, C, 
maupun $\mathrm{TT}$ (tidak terakreditasi). Sedangkan sekolah dengan akreditasi B, C dan TT, perbedaan mutu sekolahnya tidak signifikan. Kontribusi pemenuhan kedelapan SNP secara keseluruhan/simultan (nilai akhir akreditasi) terhadap mutu sekolah (Rata-rata UN) signifikan tetapi kontribusi tersebut tergolong sangat rendah, yakni hanya $7,75 \%$. Setiap peningkatan 1 poin nilai akhir akreditasi akan meningkatkan rata-rata nilai UN sebesar 0,324.

Sebagian besar sekolah jenjang SMA mendapatkan peringat akreditasi $A$ dan $B$ di tahun 2015. Namun, di antara sekolah-sekolah tersebut masih cukup banyak yang memiliki mutu sekolah yang rendah. Kontribusi pemenuhan SNP secara umum (nilai akhir akreditasi) terhadap mutu sekolah (UN murni) relatif kecil, yaitu hanya sebesar $7,7 \%$. Sedangkan sisanya dipengaruhi oleh variabel-variabel lainnya yang tidak diteliti. Persamaan regresi juga menunjukkan bahwa setiap 3 poin peningkatan pemenuhan SNP, menghasillkan 1 poin peningkatan mutu sekolah.

Gambar 1 menunjukkan perbedaan rata-rata nilai UN antarkelompok kuantil, di mana sekolahsekolah pada kuantil 5 mendapatkan rata-rata UN paling tinggi $(M=66.42 S D=12.15)$, diikuti oleh sekolah-sekolah pada kuantil $4(\mathrm{M}=63.25$ $S D=12.09)$, kuantil $3(M=63.04 S D=11.38)$, kuantil $1(M=61.81 S D=11.33)$ dan paling rendah kuantil $2(M=58.22 \mathrm{SD}=12.71)$. Hasil pengujian dengan Single-Factor ANOVA menunjukkan $\mathrm{F}(4,501)=6.193, \mathrm{p}=0.000$. Perbedaan tersebut secara statistik signifikan 0.05 sebagaimana terlihat pada Tabel 2 .

Untuk mengetahui kelompok mana yang benar-benar berbeda secara signifikan,

Tabel 2 ANOVA

\begin{tabular}{ccccccc}
\hline Kategori & $\mathrm{N}$ & Mean & $\begin{array}{c}\text { Std. } \\
\text { Dev }\end{array}$ & $\mathrm{F}$ & $\mathrm{p}$ - value & Keterangan \\
\hline Kuantil 1 & 101 & 61.81 & 11.33 & & & \\
Kuantil 2 & 101 & 58.22 & 12.71 & & & \\
Kuantil 3 & 102 & 63.04 & 11.38 & & & \\
Kuantil 4 & 101 & 63.25 & 12.09 & 6.193 & 0.000 & $\begin{array}{c}\text { perbedaan } \\
\text { signifikan }\end{array}$ \\
Kuantil 5 & 101 & 66.42 & 12.15 & & & \\
\hline Total & 506 & 62.55 & 12.19 & & & \\
\hline
\end{tabular}

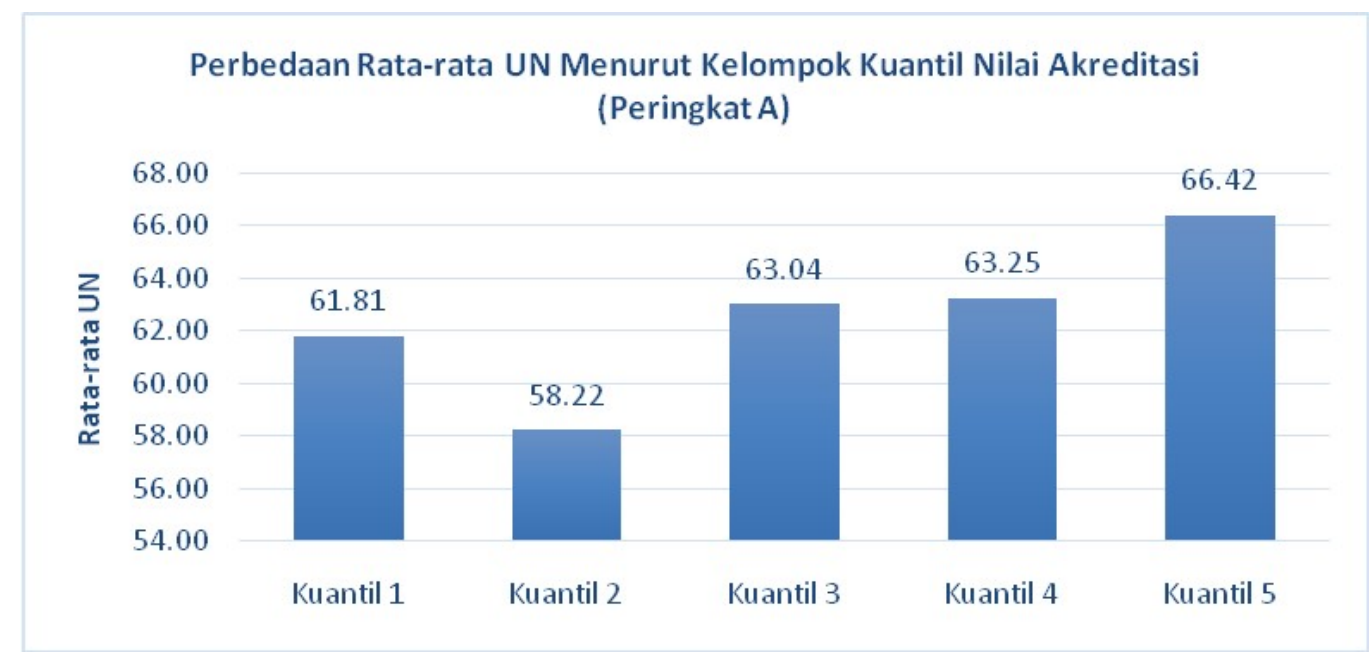

Gambar 1 Perbedaan Rata-rata Nilai UN 
pengujian dengan Post Hoc Test. Pengujian lanjutan dengan Post Hoc Test - LSD (equal variance assumed) yaitu menguji lebih lanjut pasangan kelompok kuantil mana yang benarbenar berbeda (signifikan).

Tabel 3 menunjukkan perbedaan capaian UN (nilai rata-rata UN) yang signifikan adalah antara $\mathrm{K} 1$ dengan $\mathrm{K} 2(\mathrm{p}=0.033), \mathrm{K} 1$ dengan $\mathrm{K} 5(\mathrm{p}=$ $0.006), K 2$ dengan $K 3(p=0.004), K 2$ dengan $K 4(p=0.003), K 2$ dengan $K 5(p=0.000)$, serta $\mathrm{K} 3$ dengan $\mathrm{K} 5(\mathrm{p}=0.045)$. Selain pasangan tersebut, perbedaan rata-rata UN antarkelompoknya tidak signifikan secara statistik.

Hasil pada Tabel 3 menunjukkan bahwa semakin tinggi nilai akreditasi pada satuan pendidikan menunjukkan kecenderungan terhadap perolehan UN juga tinggi. Hal ini karena pada satuan pendidikan yang telah dapat memenuhi delapan standar yang dipersyaratkan dengan nilai akreditasi tinggi maka proses belajar dapat berjalan dengan efektif sehingga diduga memiliki dampak terhadap capaian prestasi belajar siswa.

Tabel 4 menunjukkan bahwa kontribusi pemenuhan ke-8 SNP terhadap pencapaian mutu sekolah (nilai UN) sebesar $12.0 \%$, sedangkan sisanya $(88.0 \%)$ dipengaruhi oleh variabelvariabel lain yang tidak diteliti. Perbandingan pemenuhan SNP dengan mutu sekolah jenjang SMA di tahun 2015 menunjukkan perbedaan. Distribusi skor pemenuhan SNP menunjukkan sebagian besar sekolah mendapatkan skor tinggi (skewed negatif), sedangkan mutu sekolah tersebut berdistribusi mendekati normal (memiliki mutu yang bervariasi).

Terdapat provinsi yang sebagian besar sekolahnya mendapat peringkat A dan nilai UN tinggi. Terdapat juga Provinsi yang sebagian besar sekolahnya mendapat peringkat A tetapi dengan nilai UN rendah. Hal ini menunjukkan perbedaan varian SNP antardaerah dan antarsekolah. Dalam hal ini, daerah memiliki pola dan kecenderungan yang berbeda dalam usaha pemenuhan SNP, sehingga aspeknya berbeda antara sekolah satu dengan sekolah lainnya.

Dependent Variable dalam penelitian ini adalah menggunakan rata-rata UN murni. Pengaruh pemenuhan kedelapan SNP terhadap pencapaian mutu sekolah (nilai UN) secara simultan signifikan secara statistik, $F(8,497)=$

Tabel 3 Perbandingan P-Value

\begin{tabular}{c|c|c|c|c|c|}
\hline Kelompok & \multicolumn{1}{c}{$\begin{array}{c}\text { Kuantil 1 } \\
\text { (K1) }\end{array}$} & \multicolumn{1}{c}{$\begin{array}{c}\text { Kuantil 2 } \\
\text { (K2) }\end{array}$} & \multicolumn{1}{c}{$\begin{array}{c}\text { Kuantil 3 } \\
\text { (K3) }\end{array}$} & $\begin{array}{c}\text { Kuantil 4 } \\
\text { (K4) }\end{array}$ & $\begin{array}{c}\text { Kuantil 5 } \\
\text { (K5) }\end{array}$ \\
\hline Kuantil 1 (K1) & & & & & \\
\hline Kuantil 2 (K2) & 0.033 & & & & \\
\hline Kuantil 3 (K3) & 0.464 & 0.004 & & & \\
\hline Kuantil 4 (K4) & 0.392 & 0.003 & 0.899 & & \\
\hline Kuantil 5 (K5) & 0.006 & 0.000 & 0.045 & 0.060 & \\
\hline
\end{tabular}

$=$ perbedaan signikan pada level of significance 0.05

Tabel 4 Pemenuhan 8 SNP sebagai Prediktor Mutu Sekolah (Akreditasi A)

\begin{tabular}{|c|c|c|c|c|}
\hline \multicolumn{5}{|c|}{ Model Summary } \\
\hline Model & $\mathrm{R}$ & $\begin{array}{c}\mathrm{R} \\
\text { Square }\end{array}$ & $\begin{array}{l}\text { Adjusted R } \\
\text { Square }\end{array}$ & $\begin{array}{l}\text { Std. Error of } \\
\text { the Estimate }\end{array}$ \\
\hline 1 & $.346^{a}$ & .120 & .106 & 11.52505 \\
\hline
\end{tabular}


8.448, $p=0.000(p<0.05)$, sebagaimana dapat dilihat pada Tabel 5. Hal ini menunjukkan bahwa pengukuran pemenuhan standar nasional pendidikan sudah melalui instrumen yang baik.

Dari kedelapan SNP yang memiliki pengaruh signfikan terhadap mutu sekolah $(p<0.05)$ adalah standar Isi, Kompetensi Lulusan, Pendidik dan Tenaga Kependidikan, Sarana \& Prasarana, serta Pengelolaan.

Kontribusi pemenuhan kedelapan SNP secara parsial (skor setiap standar) terhadap mutu sekolah (rata-rata UN) tidak seluruhnya signifikan. Pemenuhan Standar Isi, Kompetensi
Lulusan, Pendidik dan Tenaga Kependidikan, serta Pengelolaan yang berkontribusi signifikan terhadap mutu sekolah (rata-rata UN). Tabel 6 menunjukkan bahwa kontributor tertinggi adalah pada pemenuhan terhadap Standar Pendidik dan Tenaga Kependidikan dengan nilai t sebesar 4.506. Sedangkan kontributor terendah adalah pada pemenuhan terhadap Standar Isi dengan nilai t sebesar -3.781 .

Pengujian ketepatan pemenuhan SNP sebagai prediktor menunjukkan bahwa beberapa asumsi tidak dapat terpenuhi. Dengan kata lain, penggunaan pemenuhan SNP sebagai prediktor

Tabel 5 ANOVA ${ }^{a}$

\begin{tabular}{|c|c|c|c|c|c|c|}
\hline \multicolumn{2}{|c|}{ Model } & \multirow{2}{*}{\begin{tabular}{|c|}
$\begin{array}{c}\text { Sum of } \\
\text { Squares }\end{array}$ \\
8976.747
\end{tabular}} & $\mathrm{df}$ & \multirow{2}{*}{$\begin{array}{l}\begin{array}{c}\text { Mean } \\
\text { Square }\end{array} \\
1122.093\end{array}$} & \multirow{2}{*}{$\begin{array}{l}F \\
8.448\end{array}$} & \multirow{2}{*}{$\begin{array}{l}\text { Sig. } \\
.000\end{array}$} \\
\hline 1 & Regression & & 8 & & & \\
\hline & Residual & 66014.875 & 497 & 132.827 & & \\
\hline & Total & 74991.621 & 505 & & & \\
\hline
\end{tabular}

a. Dependent Variable: Rata-Rata UN Murni

b. Predictors: (Constant), Standar Penilaian, Standar Pendidik dan Tenaga Kependidikan, Standar Pembiayaan, Standar Sarana \& Prasarana, Standar Proses, Standar Pengelolaan, Standar Isi, Standar Kompetensi Lulusan

Tabel 6 Coefficientsa

\begin{tabular}{|c|c|c|c|c|c|c|}
\hline \multirow{2}{*}{\multicolumn{2}{|c|}{ Model }} & \multicolumn{2}{|c|}{$\begin{array}{c}\text { Unstandardized } \\
\text { Coefficients }\end{array}$} & \multirow{3}{*}{$\begin{array}{c}\begin{array}{c}\text { Standardized } \\
\text { Coefficients }\end{array} \\
\text { Beta } \\
\end{array}$} & \multirow{3}{*}{$\begin{array}{c}\mathrm{t} \\
1.909\end{array}$} & \multirow{3}{*}{$\begin{array}{l}\text { Sig. } \\
.057\end{array}$} \\
\hline & & \multirow{2}{*}{$\frac{\beta}{27.710}$} & \multirow{2}{*}{$\begin{array}{r}\text { Std. Error } \\
14.518\end{array}$} & & & \\
\hline 1 & (Constant) & & & & & \\
\hline & Standar Isi & -.545 & .144 & -.203 & -3.781 & .000 \\
\hline & Standar Proses & .156 & .111 & .076 & 1.410 & .159 \\
\hline & $\begin{array}{l}\text { Standar Kompetensi } \\
\text { Lulusan }\end{array}$ & .330 & .114 & .163 & 2.893 & .004 \\
\hline & $\begin{array}{l}\text { Standar Pendidik dan } \\
\text { Tenaga Kependidikan }\end{array}$ & .438 & .097 & .213 & 4.506 & .000 \\
\hline & $\begin{array}{l}\text { Standar Sarana \& } \\
\text { Prasarana }\end{array}$ & .197 & .078 & .119 & 2.525 & .012 \\
\hline & Standar Pengelolaan & -.328 & .123 & -.134 & -2.664 & .008 \\
\hline & Standar Pembiayaan & .097 & .103 & .042 & .940 & .347 \\
\hline & Standar Penilaian & .068 & .123 & .027 & .555 & .579 \\
\hline
\end{tabular}


mutu sekolah masih kurang tepat dan dapat menimbulkan bias prediksi. Terdapat hubungan positif, kuat, dan signifikan antarpengukuran pemenuhan SNP. Hal ini menunjukkan masih terdapat kelemahan pada pengukuran 8 SNP pada hasil ukur antarstandar yang tidak saling independen.

Terdapat hubungan positif, kuat, dan signifikan antarbutir dalam standar yang berbeda dalam pengukuran pemenuhan SNP. Hal ini menunjukkan masih terdapat sejumlah butir pada tiap standar yang saling terkait dengan butir pada standar lainnya (tidak saling independen).

Analisis hasil akreditasi secara keseluruhan dikelompokkan dalam kuartil 1 sampai dengan kuantil 5. Sebagian besar data menunjukkan pengelompokan kuantil lebih tinggi nilai ratarata UN pada kuantil 5. Artinya, pendidikan dengan akreditasi A memiliki kencenderungan hasil rata-rata UN juga tinggi. Satuan pendidikan yang mendapatkan akreditasi A setiap standar telah terpenuhi sehingga dapat mendukung dalam pelaksanaan proses belajar. Guru yang sudah memenuhi kualifikasi pendidikan S-1 dan telah mengikuti sertifikasi dapat melaksanakan proses belajar secara profesional. Guru SMA/ MA (96\%) berlatar belakang pendidikan minimal D-4 atau S-1 dan sebanyak 87\% guru SMA/MA mengajar sesuai dengan kewenangan mengajar (Fahmi, 2013). Sekolah yang terakreditasi A kualifikasi guru mengajar sudah terpenuhi sehingga dapat mengajar dengan efektif. Dengan demikian kecenderungan sekolah yang terakreditasi A dapat menjadi gambaran mutu pada satuan pendidikan tersebut.

Apabila dilihat dari hasil analisis kontribusi kedelapan SNP terdapat standar yang memiliki kontribusi secara signifikan yaitu Standar isi, Kompetensi Lulusan, Pendidik dan Tenaga Kependidikan, Sarana \& Prasarana, serta Pengelolaan. Standar yang lain juga memiliki kontribusi tetapi tidak signifikan. Hal ini menunjukkan bahwa hasil akreditasi SNP sebagai prediktor mutu sekolah masih kurang tepat dan dapat menimbulkan bias prediksi. Karena beberapa asumsi tidak dapat terpenuhi (normalitas dan heteroskedastisitas). Namun demikian, dalam pemenuhan SNP bagi satuan pendidikan memberikan harapan pada peningkatan mutu pendidikan. Penelitian Raharjo (2014) menyebutkan bahwa sumbangan delapan standar nasional pendidikan terhadap proses pembelajaran sebesar $22,5 \%$. Hal ini berarti bahwa 77,5\% keberhasilan proses pembelajaran ditentukan oleh faktor lain baik internal maupun eksternal seperti motivasi, minat, latar belakang orang tua, lingkungan sekolah, dan lain sebagainya. Faktor-faktor di luar standar nasional pendidikan perlu diperhatikan dalam pencapaian mutu pendidikan.

\section{SIMPULAN DAN SARAN}

\section{Simpulan}

Hasil penelitian menunjukkan, pertama bahwa sekolah dengan akreditasi A yang dikelompokkan pada kuantil rata-rata capaian hasil UN tidak menunjukkan perbedaan antarkuantil 3, 4 dan 5 secara signifikan. Hal ini menunjukkan bahwa hasil akreditasi A dapat menggambarkan kondisi mutu pendidikan, karena pada posisi sekolah yang terakreditasi A pada rata-rata UN antarkuantil tidak menunjukkan perbedaan. Hasil akreditasi dapat memberikan prediktor dalam menggambarkan mutu pendidikan pada satuan pendidikan walaupun belum sepenuhnya menjadi prediktor yang tepat. Kedua, berdasarkan analisis hasil akreditasi bahwa pengaruh pemenuhan ke-8 Standar Nasional Pendidikan terhadap pencapaian mutu sekolah (Nilai UN) secara bersama-sama (simultan) signifikan secara statistik. Dari ke-8 SNP yang memiliki pengaruh signfikan terhadap mutu sekolah yaitu standar Isi, Kompetensi Lulusan, Pendidik dan Tenaga Kependidikan, Sarana \& Prasarana, serta Pengelolaan. Hal ini menunjukkan bahwa hanya ada 5 standar yang berpengaruh secara positif dan signifikan terhadap pencapaian mutu 
sekolah. Sementara standar proses, standar pembiayaan, dan standar penilaian berpengaruh positif tetapi tidak signifikan. Hal ini berarti bahwa hasil akreditasi dapat merupakan prediktor mutu pendidikan, namun masih belum sepenuhnya dapat menjadi prediktor dalam menggambarkan mutu pendidikan yang tepat.

\section{Saran}

Berdasarkan simpulan yang dihasilkan dapat disarankan sebagai berikut. Pertama, sekolah, Pemerintah Daerah, dan Pemerintah Pusat secara bersama-sama dan terencana serta berkolaborasi untuk berusaha memenuhi delapan Standar Nasional Pendidikan. Bagi sekolah yang telah berhasil mendapatkan akreditasi A dapat memberikan kontribusi pada pencapaian mutu pendidikan. Kedua, bagi satuan pendidikan yang telah memenuhi standar nasional pendidikan juga perlu memperhatikan faktor internal dan faktor eksternal misalnya motivasi, minat, latar belakang orang tua, lingkungan sekolah, dan lain sebagainya yang dapat berkontribusi pada mutu pendidikan. Faktor di luar standar cukup signifikan berkontribusi pada capaian mutu sekolah.

\section{PUSTAKA ACUAN}

Cahyana, A. (2010). Upaya peningkatan mutu sekolah melalui melalui otonomi satuan pendidikan, Jurnal Pendidikan dan Kebudayaan, 16(2) 109-117.

Fahmi. (2013). Kemampuan penguasaan materi pelajaran guru SMA/MA berdasarkan ujian nasional rendah. Jurnal Pendidikan dan Kebudayaan, 19(2) 189-205.

Goetsch, D.L. \& Stanley, D. (2006). Quality management, 5th Edition. University of West Florida and Oskaloosa-Walton.

Lochmiller, C.R. (2014). What would it cost to coach every new principal? An estimate using statewide personnel data. Education Policy Analysis Archieves. 22(55) 1-15.

Sukmadinata, N.S. (2003). Landasan psikologi proses pendidikan. Bandung: Remaja Rosdakarya.

Saraswati, N.M.V. (9 Maret 2017). Budaya literasi dan kematangan berdemokarasi. Surat Kabar Media Indonesia.

Peraturan Pemerintah Nomor 19 Tahun 2006 tentang Standar Nasional Pendidikan.

Peraturan Pemerintah Nomor 32 Tahun 2013 tentang Perubahan Peraturan Pemerintah Nomor 19 Tahun 2005.

Prayekti. (2013). Pengaruh pembelajaran kooperatif STAD versus ekspositori terhadap hasil belajar pemahaman dan aplikasi konsep IPA siswa kelas IV sekolah dasar. Jurnal Pendidikan dan Kebudayaan, 19(4) 451-471.

Kementerian Perencanaan Pembangunan Nasional/Bappenas. (2009). Rencana Pembangunan Jangka Menengah Nasional 2010-2014 https://www.bappenas.go.id/id/publikasiinformasi-aplikasi-dan-tautan/publikasi/rpjmn-2010-2014/, diakses 5 Maret 2018.

Kementerian Pendidikan dan Kebudayaan. (2015). Rangkumanan Statistik Pendidikan Dasar dan Menengah 2014/2015. Pusat Data Statistik Pendidikan dan Kebudayaan.

OECD.(2016). PISA 2015 Results (Vol. 1): Excellence and equity in education, PISA. Paris: OECD Publishing.

Raharjo, S.B. (2014). Kontribusi Delapan Standar Nasional Pendidikan terhadap Pencapaian Prestasi Belajar. Jurnal Pendidikan dan Kebudayaan, 20(4) 470-482. 
Robinson, V.J.M. (2009). School leadership and student outcome: Identifying what work and Why: Best Evidence Synthesis Iteration, New Zeland: Ministry of education.

Safari.(2015). Ujian nasional sebagai cermin mutu pendidikan dan pemersatu bangsa. Jurnal Pendidikan dan Kebudayaan, 21(2) 101-113.

Republik Indonesia. (2003). Undang-undang Nomor 20 Tahun 2003 tentang Sistem Pendidikan Nasional.

Widyastono, H. (2013). Minat terhadap profesi guru, pengetahuan tentang penilaian hasil belajar, dan kualitas kurikulum buatan guru. Jurnal Pendidikan dan Kebudayaan, 19(2) 222-235. 